\title{
Türk Destanlarında Geçen Halı Anlatımları, Halılardaki Hayvan Motifleri ve Renklerinin Dili
}

Mehmet ÖZKARTAL* and the Language of Colors in Turkish Epics

\section{ÖZET}

Türk mitolojisinin toplumsal yaşam içerisindeki özgünlüğü edebi alanda ne kadar geçerli ise sanat alanında da o kadar geçerliliğge sahiptir. Mitolojik anlatımlar geçmişten günümüze kadar gelmiş olan toplumsal yaşantı döngüsü içerisindeki her türlü sosyal ve yaşamsal olayları içinde barındırarak toplumun savaşlarını, barışlarını, inançlarını, karakterini ve sanatındaki ince nüanslar ile duygusal yapısını ortaya koyar. Sanat eserlerindeki görüntüler ise, yeri gelir halısındaki bir motifte, yeri gelir çanak ve çömleklerinde veya mimari eserleriyle kendini ortaya çıkartır. Türk mitolojisi ve destanlarında da bu toplumsal olaylar ve sanatsal ibareler her zaman mevcuttur. Bu araştırmada, Türk destanlarında geçen halı anlatımları, halılardaki hayvan motifleri ve halı sanatında kullanılan renklerin Türk toplumu üzerindeki etkileri ele alınmaya ve analiz edilmeye çalışılmıştır.

Anahtar kelimeler: Türk Mitolojisi, Türk Destanları, Halı, Hayvan Motifleri, Renklerin Anlamları.

\section{Giriş}

Mitoloji, doğa ve toplum yaşamı üzerine işlenmiş olan hayallerde canlandırılarak (veya onları canlı görerek) anlatılma şeklidir. Eski çağlarda yaşamış olan insanların doğa olaylarına, sosyal ilişkilerine, dini inançlarına karşı bakış açılarının yorumlanmasıdır.

\footnotetext{
* Yrd. Doç. Dr., Süleyman Demirel Üniversitesi, Eğitim Fakültesi, Güzel Sanatlar Eğitimi Bölümü, Isparta, e-posta: ozkartal1968@hotmail.com
}

\section{Carpet Narrations, Animal Motifs}

(1)

\section{ABSTRACT}

The originality of Turkish Mythology in social life has some equal amount of validity both in literary and artistic way of life. Mythological narrations embrace in any kind of social and vital events within the circle of social life from the past to the present time and reveal the wars, reconciliations, faith, character, fine nuances in art through a sentimental structure. As for the images in artistic works, it reveals itself with a motif on the carpet or potteries or through architectural works. These social events and artistic phrases always exist in Turkish mythology and epics as well. In this study, we try to explain and analyze the effects of carpet narrations, animal motifs on carpets and colours used in the art of weaving carpets of Turkish society.

Keywords: Turkish Mythology, Turkish Epics, Carpet, Animal Motifs, Meaning of Colors.

Bir başka deyişle, trans haline geçmiş rahiplerin, büyücülerin, Şamanların doğa üzerinde gördükleri resim ve şekilleri, doğaüstü olaylarla süsleyerek anlattıkları, bir gerçekliğin nasıl yaşama geçtiğini gösteren hikâyelerdir. Her millet ülkesinin tarihini, çeşitli efsanelerini, destanlarını, kahramanlık öykülerini, inanç sistemini, Tanrılarını, insanlarını, masallarını, söylencelerini bünyesinde barındırmış, bunları halı, kilim gibi günlük kullanım araçları üzerine aktararak yaşantısında yer vermiş, gittiği her yere taşır hale gelmiştir.

M.Ö. XII. yüzyıldan daha eski olduğu düşünülen ve tarih sahnesinde ilk Hun'larla anlatılmaya başla- 
nan Türk tarihi, Orta Asya dediğimiz uçsuz bucaksız bölgede göçebe atlı kültür olarak yüzyıllar boyunca geleneklerini muhafaza etmiştir. Atlı kültür, Minussinsk bölgesinde, Tagar gölü ve adasının, Altaylarda ise Mayamir bozkırının adını taşımıştır. Altay ve Tanrı Dağlarında çok tanınan İskitler ve Saka adı ile adlandırılan kavimlerin sanatında hayvan üslubunun doğduğuna ve geliştiğine şahit olunmuştur. Sanatın, toplulukların maddi ve manevi değerlerinin aynası olduğu düşünülürse, Şibe, Katanda, Başadar, Berel, Tüekta, Pazırık ve Noin-Ula kurganlarından çıkan halılar, kap kacaklar, ağaca oyulmuş mistik hayvan figürleri, vahşi hayvanların mücadele sahneleri kabartmaları, süs eşyaları, eyerler, koşum takımları ve eyer altı örtüleri gibi eserlerde, toplumun dinamik çizgileri ile zengin form anlayışını ve hayat dolu sanatını daha iyi anlamamız mümkün olmuştur (Diyarbekirli 1972: 38). Örneğin; bugün Tibet'te bulunan ve Oktay Aslanapa tarafından son yıllarda tanıtılan, Selçuklu döneminden kaldığı kabul edilen, sayıları 12'yi bulan örneklerden 4 tanesinin hayvan figürleriyle süslü olduğu, sipariş üzerine Anadolu'da dokunarak Tibet'e götürüldüğü, yünlerinin cinsi, renk ve teknik açıdan diğer Anadolu Selçuklu halıları ile benzerlik gösterdiği belirtilmektedir (Deniz 2000: 25).

Halı-kilimin sanatının yapımı toplum içerisinde basit bir sosyal faaliyet olmayıp, sosyal grubun veya bir milletin sosyal tarihinin altın sayfaları dile getirilmektedir. Halı-kilim ve mezar taşları gibi etnoğrafik damgalar birer sanat eseri olmaktan öte, bir duygunun, bir sosyo-kültürel hayatın, en genel tabiri ile sosyal tarihin vesikalarıdır. Başka bir deyişle "motif, figür, sembol ve şekillerin tarihin belli bir noktasındaki zihniyet ve tutumların ürünleri olduğu açıktır" (Mülayim 1996: s.222).

Rus arkeolog Rudenko başkanlığında 1947 yılında yapılan kazılar sonucunda bulunmuş olan kurgandaki eşya ile halıyı İskitlere mal ederek MÖ 5. yüzyıla tarihlendirmiştir. Daha sonraki yayınlarda ölülerin gömülmesi âdetleri, mumyalanmış ölülerin tipleri ve Altay bölgesinin tarihi ile komşu kurganlarda çıkan diğer eserler karşılaştırılınca, halının Asya Hunları'na ve MÖ 3-2. yüzyıllara mal edilmesi akla yakın gelmektedir.

Toplumsal yapının ve yaşamın ihtiyaç duyduğu ürünlerden olan halı-kilimlerin tarih sahnesine çıkışı net olarak bilinmemekle beraber, Altay bölgesindeki V. Pazırık kurganında bulunmuş olan Pazırık halısının dünyada bilinen en eski halı olduğu (Ancak bundan daha eski halı parçaları bugünkü Doğu Türkistan'da bulunmuştur) ve bu bölgelerin tarihin bilinen devrinden bugüne kadar Türkler tarafından kullanılan yerleşim yerleri olduğu da kabul edilmektedir. V. Pazırık kurganından çıkarılan ve dünyanın bilinen ilk halısı olarak kabul edilen, üzerinde pars damgası ile at, sığın figürlü, eyer ve pantolonlu süvari resimleri olan halı günümüze kadar bozulmadan kalabilmiştir. Üzerindeki figürlerden anlaşıldığı üzere at eyerinin Türk buluşu olması ve atlı süvarilerin giyiniş tarzıyla Pazırık halısının Türk kültürüne ait olduğunu ispatlama açısından önemli ipuçları vermektedir.

Göçebe toplumların sosyal yapılarında, yaşam biçimlerine göre oluşmuş en belirgin kavramlar olan doğurganlık ve bereketlilik, doğa ve vahşi yaşam canlıları kutsanmış; daima, iç içe yaşadıkları ve mücadele halinde oldukları hayvanlar, içinde bulundukları koşulların etkisi altında sembolik hale gelip, sanatlarına yansımıştır (Özhekim 2007: 133). Halı-kilimin ortaya çıkışının temelini oluşturan göçebe hayat yaşantısı ile atın ve koyunun ehlileştirilmesi olmuştur. Halı-kilim sanatı ile koyunun ehlileştirilmesi, göçebe hayatın şartlarından dolayı çadırların içinin döşenmesi ve çadır için gereken keçenin temin edilmesi arasında yakın bir ilişki vardır. Step kuşağının en karakteristik göçebe kavimleri Türk kavimleri olduğu için halı yapımı ve yayımı bakımından oynadıkları rolün çok büyük olduğu yolundaki düşüncelerde tabidir. Atla beraber koyun bozkır şatlarının vazgeçilmez hayvanıdırlar (Aksoy 2007a: 92). Türk sanatının en önemli üsluplarından biri olan hayvan üslubunun da bu kültürle ortaya çıktığı belirtilmektedir.

Türkler koyunların yünlerinden keçeler yapmışlar ve koçbaşlarını da keçelerine, kilimlerine- halılarına vb damga olarak işlemişlerdir. Örneğin “... Yenisey'in yukarı akımında ve Uygurlardan sonra bir müddet Moğolistan'da yaşayan Kırgızların halıları da keçe cinsindendi. Bunlarda kullanılan bezek motiflerine yerliler "koçkardıng müzü" (koçların boynuzu) derler. Türklerin hala keçeden ayakkabı-çizme yaptıklarını ve üzeri koçbaşlı nakışlarla işlenmiş keçeleri, bütün Türk Cumhuriyetlerinde görmek mümkündür" (Aksoy 2007b: 155).

Hayatlarını avcılık ve hayvancılıkla kazanan insanlar doğada bulunan tüm canlı ve cansız varlıkların, zor doğa şartlarına en iyi şekilde uyum sağlayabilen hayvanların yaşamını yakından izlemiş ve onlara hayranlık duymuşlardır. Hayvanların doğadaki davranışlarını, yaşam tarzlarını ve karakterlerini öğrenen insan, bu canlı varlıklara sembolik manalar yüklemeye başlamıştır. Aslan gücü ve kudreti, kartal göklerin hâkimiyetini, kurt vahşiliği, korkusuzluğu, yol göstericiliği, önderliği, liderliği göstermiştir. Örneğin; Ergenekon Destanı'nda, Türeyiş Destanı'nda, Bozkurt Destanı'nda kurt, Türk toplumunca simge haline gelmiş, Türkler için $O$, özgürlüğün, gücün ve yol göstericiliğin simgesi olmuştur.

Hayvan üslubunun ortaya çıkışı dini inanış ve anlayışlarla ilgilidir. Bütün bunlar Gök-Yer-Su ve ata- 
larla ilgili oluşturulan dini sisteme dayanır. Zamanla Şamanizm de önemli bir kaynak olmuştur. Bunlara bağlı gelişen mitoloji ve kozmoloji hayvan tasvirleri yapılmasına etkendir. Böylece hayvanların, insanların türediği hayvan-ata veya hayvan-ana olarak kabul edilmesi, koruyucu ruh olduklarına inanılması, kalıntılarına saygı gösterilmesi gibi nedenler, hayvan tasvirleri yapılmasına ve zamanla bu yöne ağırlık veren bir sanatın doğmasına yol açmıştır.

Hayvan isimleri Türk boylarında hanlara, beylere unvan olarak ta verilmiştir. Kırzıoğlu, (1987: 921) “Milli Destanlarımızdan Dede Korkut Oğuznameleri'nin Tarih Belgesi Bakımından Değerleri-Armenya/Yukarı Eller Tarihi'nin İçyüzü" adlı çalışmasında bu konuyu şöyle açıklamıştır.

Horasan-Sakaları kolundan çıkan ve İran dini (Zerdüştlük) tesiri altında kalan Arşaklılar, milli Türk an'anesine, kurucudan sonuncuya (M.Ö.250M.S.227) kadar bağlıydılar. Bunların hepsinin kullandığı "Arşak unvanı"da Türkçe olup, "Pars (Babur/ Bebir) ile Ayı Karması Yırtıcı" anlamındadır ( XV. Yüzyılda Türkçeye çevrilen, "Acaibü'l Mahlukaat” kitabı). Eski atalarımızda, güçlü hayvan adlarını unvan olarak kullanmak, Padişahların geleneği idi: Sakalı Cihangir Afrasyab (M.Ö.654-626), Türk kaynaklarında, "Alp-Er Tonga/Tönge = Alp-Er Pars/Babur"; Gayrimüslim Yakabular'ın 1046'da Karahanlı'ları bunaltan hükümdarının unvanı "Böke = Evren, Ejderha”; Müslüman Karahanlılar'ın bütün Padişahlarında görülen "Arslan ve Buğra (erkek deve) unvanları gibi.

Türk mitolojisinde Anka, Simurg, Garuda, Grifon, Ejder gibi fantastik hayvanlar geçmekte iken Dede Korkut Destanı'nda İslam kültürünün de etkisi ile olmalı ki, hayvanlar genelde avlanılan ya da kahramanlar için savaşılan canlılar olarak karşımıza çıkmıştır.

Geçmişten günümüze her bir halı-kilim türü dokumada desenler, motifler ve renkler dokuyucuların ifadelerinin birer simgesi olmuştur. Köklü bir geçmişe sahip olan Türk halı sanatı içinde yer alan hayvan figürlü halıları dokuyanlar, hiçbir görsel sanat eğitimi almamalarına rağmen, geçmişten itibaren gelişerek gelen estetik birikimle, görsel anlatım dilinin kavramsal özelliklerini halıların yüzeylerine yansıtmışlar, hayvan figürlü halıların yüzeyinde geometrik üslupta çeşitli hayvan motifleri (kuş, geyik, ejder vb) kullanmışlardır.

İç Asya'nın bozkırlarında dağınık ve göçebe halde yaşayan Proto-Hunların sanata olan eğilimleri önemlidir. Sanatçılar, konuları değişik açılardan görmekle ve belli kalıplar üzerinden işlemekle geleneksel sembolizme zorlanmışlardır. Bozkırda gelişen “Hayvan Üslubu”nun Orta Avrupa'ya ve Ön Asya'ya kadar yayılmasının ve uzun zaman devam etmesinin açıklaması, desenlerinin yalnız süslemek için yapıl- dığında aranmamalıdır. Bu desen köklerinin Hunların atalarının, doğaüstü kuvvetlere karşı inançlarından ortaya çıktığı da göz önüne alınmalıdır (Diyarbekirli 1969).

Gün yüzüne çıkartılan tüm bu buluntuların aynı zamanda sancak ve tuğ sopalarının ucunda da takılı olması Şamanist Türk inancında koruyucu bir anlam taşıdıklarının da göstergesidir. Kam'ın doğaüstü dünya ile ilişkiye geçerek, halkın çeşitli sıkıntı ve isteklerine çare bulmak için yukarı ve aşağı dünya yolculuklarında kendisine, kartal, ördek, kaz, geyik, at, ayı, kurt gibi çeşitli hayvanlar yardımcı olmaktadır. Şaman bunların yardımıyla veya onların biçimine bürünerek gökyüzüne çıarak tanrılardan, ruhlardan, Gök Tanrı'dan ya da Ülgen'den gerekli şeyleri alır ve insanların yardımına koşar, dertlerine çare bulur ve hastalıklarını iyileştirir. Bu hayvanlardan biri mutlaka Kamın koruyucu ruhudur (Çoruhlu 2002: 67).

Her bir halkın sanatında ortaya çıkan motifler, onların icra tarzı, o halkın yaşamı, dünyaya bakışı, mitolojik tefekkürü ile bağlı olup önce inançlarında, dini görüşlerinde, sonra sözlü edebiyatında ortaya çıkar ve daha sonra sanat eserlerine yansır. Ejder motifinin de böyle köklü motiflerden olduğu kuşkusuzdur. Ejder motifi, değişen dini ve sosyal anlayışlara rağmen mimaride, seramikte, çinide, ahşap ve maden sanatlarında, dokumalarda hep kullanılmış bir motiftir. Birçok kaynaklara göre Orta Asya'nın doğusunda yaşayan Türk kavimlerinde, Azerbaycan, Volga boyu ve Başkurt Türklerinde ejder su kaynaklarını, yağmur bulutlarını temsil ediyordu. Uygur ve Çin kozmolojisinde ise doğunun, baharın, gök renginin ve ağacın simgesi idi. Tibet panteonunda Kök-luu, gök gürültüsü ve yağmur tanrısı olarak yer almıştır. Moğol mitolojisinde ejder, -Lu- suyun sahibi ve gök tanrılarından biri olarak bilinmektedir. Kıpçak Türklerinde aile ocağının koruyucusudur ve Kıpçakların rivayetlerine göre insanlar, yılan (ejder) Begşa'dan türemişlerdir (Paşayeva 2008: 1081). Ejderha resimleri, birçok eserde yalnız olarak tasvir edildiği gibi, birçok efsane, destan ve hikâyelerde kahramanların gücünü ve başarısını temsil eden, ejderha öldürme sahneleri tasvir edilmiştir.

Eski yapıtlarda ejder motifinin yanında çoğu zaman belirli süsleme şekilleri kullanılmıştır ve bunların ilki kızıl renkli bir küredir. Bu kürenin güneş ve ayı temsil ettiği sanılmaktadır. Bundan başka bulut, helezon, ağaç, lotus, nilüfer, "evren gülü" denilen yabani nergis motifleri de sıkça ejderle beraber görülebilir. Karamağaralı'ya göre hem ejder hem de lotus çiçeği tanrısal gücü simgeler ve onların bir arada kullanılması, tanrısal gücün bir çeşit göstergesidir. Azerbaycan halı sanatında ejder motifinin hem eski Türk mitolojisinden gelen iyilik, su ve bolluk, bereket 
sembolü olarak işlendiği, hem de Ateşperestlikten gelen kötülük, şer kuvvetlerin sembolü olarak işlendiği örnekler vardır (Paşayeva 2008: 1082).

Çoruhlu, "Türk Mitolojisinin Anahatları" kitabında; "Bu fantastik hayvanlar farklı kültürlerde yer almakla birlikte özde birbirlerinden türemiş oldukları söylenebilir" diyerek, Simurg'un İran mitolojisine, Anka ya da Zümrüdüanka'nın Arap-İslam kültürüne, Garuba'nın Hint mitolojisine, Karakuş'un (muhtemelen Kartal) Türk kültürü ve mitolojisine ait olduğunu söylemektedir. Ayrıca "ejderha bütün dünyada Çin mitolojisi ve sanatına ait kabul edilse de, Türk mitolojisi ve sanatında da büyük yer tutmuştur. Bu masal hayvanı, gök, yer-su unsurlarına bağlı olarak geniş bir uygulama alanı bulmuştur" demektedir (Çoruhlu 2002: 132). Efsane, destan, hikâye ve masallarda geçen bu varlıkların mitolojik boyutları sözlü anlatımla, yazılı eserlerle dile gelirken, sanatçıların çalışma alanına girerek, simgesel anlamları ve görsel temaları ile sanat eserlerinde yerini almaktadır.

Avrasya hayvan üslubunda, İslam dünyasında ve Selçuklu sanatında yaygın olan hayvan motifleri arasında en çok kullanılanlarından biri de kartal motifidir. Kartal iriliği yırtıcılığı, görkemli görünüşü ile eski Türklerde sembol olduğu kadar arma ve totem olarak da kullanıldığı bilinmektedir. Pazırık kurganlarında gün ışığına çıkarılan bir keçe süste kartalın ne derece tanrılaştırılmış ve kutsal bir şekle büründüğü görülmektedir (Özhekim 2007: 134).

Hun sanatında kartal motifinin önemli bir yer tutması; kartal'ın şamanın koruyucu ruhu olmasının dışında, yine Şamanist inanışa göre Şaman'ların yeryüzüne bir kartal tarafından getirildiği ve aynı zamanda kartalın Tanrının gölgesi olarak görülmesi düşüncesinden kaynaklandığı şeklinde açıklanabilir. Ayrıca en büyük yeminler onun adına yapılır, kısır

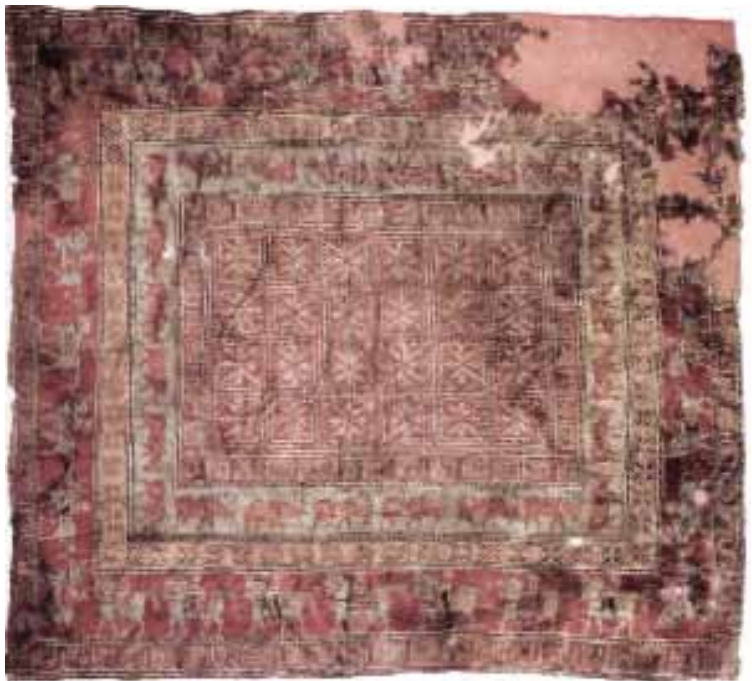

Foto 1. V. Pazırık Kurganından Çıkarılan Halı kadınlar çocuk vermesi için ona yalvarır ve bundan sonra meydana gelen çocuğa da "kartaldan türemiş" denirdi (Uzun 2007: http://egitimdergi. pamukkale. edu.tr).

Halılarda geçen at unsuru ise Türk toplumunun vazgeçilmez bir ongunudur. Destanlarda "sana at demem, kardaş derim" sözleri ile de ata verilen değerin büyüklüğü ortaya konmuş ve sanata yansımıştır. Geç Han dönemine ait eserlerde Hunların (ve Çinlilerin) süvari atları, kuyrukları kesilmiş veya düğümlenmiş olarak tasvir edilmiştir. Aynı özellik Pazırık halısının iri atlarında da görülmektedir. Dıştan içe ikinci ve geniş bordürde,28 tane kuyruğu bağlı ve başlarında sorguç bulunan atlar, geyiklerin ters yönünde sıralanmışlardır. Türk döneminde hemen hemen bütün at tasvirlerinde kuyruklar düğümlenmiştir. Dede Korkut Destanı hikâyelerinden olan Bamsı Beyrek'te de Türk geleneği olarak, Bamsı Beyrek'in ölümü üzerine atının kuyruğunun bağlandığı (ağ boz atının kuyruğunu kestiler) anlatılmaktadır (Esin 2004: 282). Bu hikâyedeki özellik Pazırık halısının dördüncü bordüründe de görülmektedir. Tırısla giden atlar, bu atlara binmiş veya bir aşırı olarak yanında yürüyen insan figürleri, bu figürlerin kıyafetleri bütün bordür boyunca gerek renk gerekse biçim bakımından aynı özelliklere sahiptir. Atların hepsinin renkleri aynı, yeleleri traşlı, kuyrukları bağlıdır. Atların kuyruklarının bağlanması ve yelelerinin kesilmesinin Türklerde bir yas alameti olduğu ileri sürülmektedir (Karamağaralı 1998: 175).

Hunların ve İskitlerin özellikle geyiğe olan eğilimleri yüzünden Avrasya bozkırlarında çeşitli malzemeden yapılmış tabiatçı görüşle ya da üsluplaşmış sayısız geyik figürüne rastlanmıştır. Bugün bile Anadolu'da hala bir "Alageyik" efsanesi masalları süslemeye devam etmektedir (Diyarbekirli 1969).

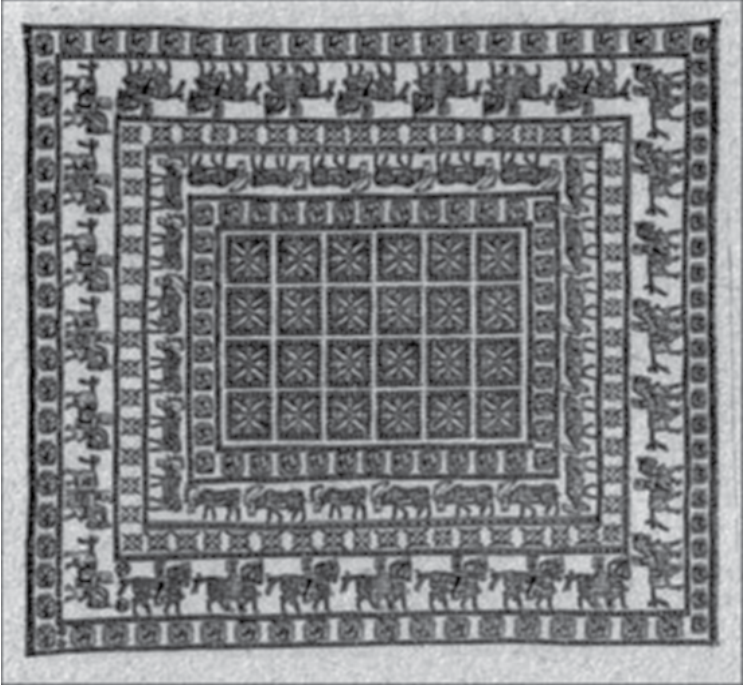

Foto 2. Pazırık Halısının Şematik Çizimi 


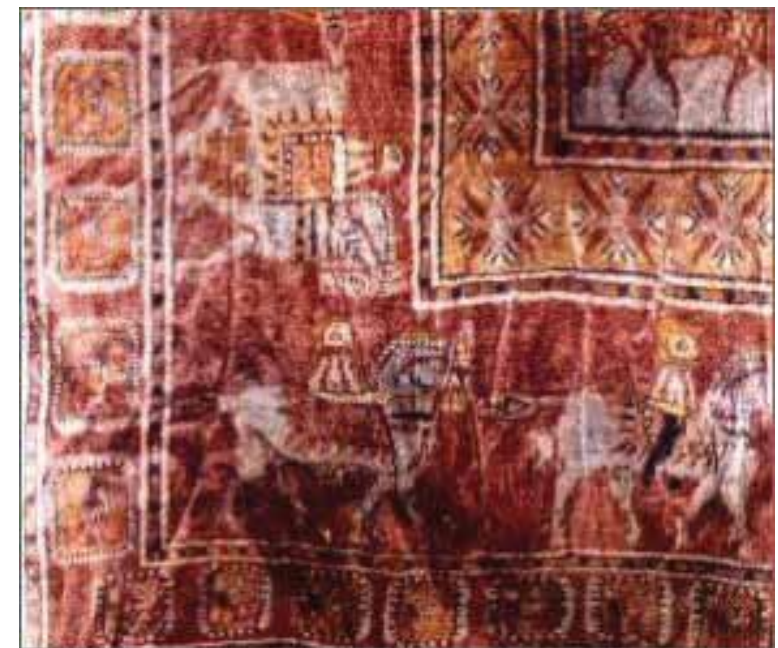

Foto 3. Pazırık Halısının Kenar Bordürdeki Atlı Süvariler

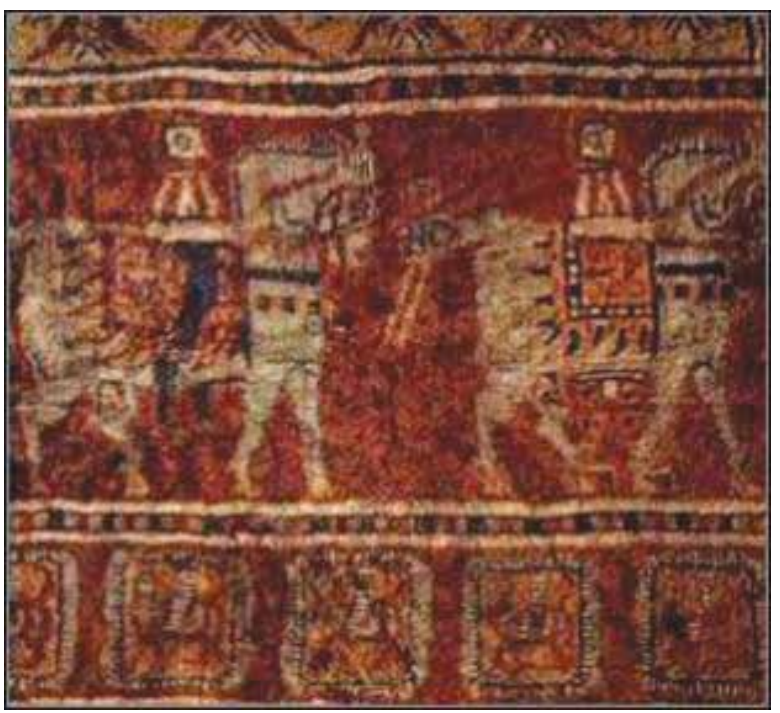

Foto 4. Pazırık Halısının Kenar Bordür Detayı

Pazırık halısının İçteki ikinci bordüründe de, birbiri arkasında yürüyen 24 tane sığın soyundan geyikler sıralanmıştır. Geyik figürleri İç Asya'da yaşayan geyiklere benzemektedir. Bu geyiklere İran'da da rastlanır. Geyik üzerindeki şekiller Türk hayvan üslubuna ait tasvirleri içermektedir. Ayrıca halının iç ve dış bordürleri birer dikdörtgen içine yerleştirilmiş çift boynuzlu grifonlarla süslenmiştir. (Foto 5 .)

Oğuz Kağan Destanı'na göre, Oğuz Kağan'ın 6 oğlunun her birinin 4'er oğlundan toplam 24 torunu olmuş, bu 24 torun da atası oldukları 24 Oğuz boyuna kendi adlarını vermişlerdir. Halının zemininin 24 kareye bölünmüş olması hem Asya Hunları'nın $24^{\prime}$ lü devlet örgütünü, hem de Oğuzların 24 boyunu hatırlatmaktadır. Ayrıca da geyiğin 28 adet olması, Hun'lar gibi Kök-Türk'lerde de Tanri'dan kut almış sayılan devletin 28 dereceli düzenini (hiyerarşi) anımsatıyor (Tekçe 1993: 155). Pazırık halısındaki 24 kare, tarih boyunca Türk topluluklarının halılarında, ana düzenin çıkış noktası olmuştur (Kırzıoğlu 2001: 59). (Foto 1-4, 6-8.)

Halı simgeciliği Türk Destanlarında sıkça rastlanmamasına rağmen Dede Korkut destanı'nın bazı hikâyelerinde halı ve keçeye yer verilmiş, halıya verilen değerin yanında bir de sevgi unsuru yüklenerek "ipek halıık" denilmiştir (Ergin 2007: 21).

Dirse Han oğlu Boğaç Han hikâyesinde halı ve renk simgeciliği şöyle vurgulanmaktadır. "Bir gün Kam Gan oğlu Han Bayındır yerinden kalkmıştı. Şami otağını yeryüzüne diktirmişti Alaca gölgeliği gökyüzüne yükselmişti. Bin yerde ipek halıı̆̆ı döşenmişti. Hanlar hanı Bayındır yılda bir kerre ziyafet verip Oğuz beylerini misafir ederdi. Gene ziyafet tertip edip attan aygır, deveden erkek deve, koyundan koç kestirmişti. Bir yere ak otağ, bir yere kızıl otağ, bir yere kara otağ kurdurmuştu. Kimin ki oğlu kızı yok, kara otağa kondurun, kara keşe altına döşeyin, kara koyun yahnisinden önüne getirin, yerse yesin, yemezse kalksın gitsin demiştir. Oğlu olanı ak otağa, kızı olanı kızıl otağa kondurun, oğlu kızı olmayana Allah Taala beddua etmiştir, biz de beddua ederiz, belli bilsin demiş idi. ... Bayındır Han'ın yiğitleri Dirse Han'ı karşıladılar. Getirip kara otağa kondurdular. Kara keçe, altına döşediler" (Ergin 2007: 21).

Kam Püre'nin oğlu Bamsı Beyrek hikâyesinde ise; "Kam Gan oğlu Han Bayındır yerinden kalkmıştı. Kara yerin üstüne ak otağını diktirmişti. Alaca gölgeliği gökyüzüne yükselmişti. Bin yerde ipek halıcığı döşenmişti... Boz oğlan babasının evine geldi. Babasına haber verildi bezirgânlar geldi diye. Babası sevindi, çadır otağ, alaca gölgelik diktirdi, ipek halııılar serdi, geçti oturdu" (Ergin 2007: 58).

Salur Kazan'ın evinin yağmalanması hikâyesinde; "Bir gün Ulaş oğlu, yırtıcı kuşun yavrusu, zavallının biçarenin ümidi, Amıt suyunun aslanı, Karacuğun kaplanı, yağız al atın sahibi, Han Uruz'un babası, Bayındır Han'ın güveyisi, kudretli Oğuz'un devleti, kalmış yiğit arkası Kazan yerinden kalkmıştı. Doksan başlı otağlarını kara yerin üzerine diktirmişti. Doksan yerde alaca hal, ipek döşemişti" (Ergin 2007: 38).

Kazan Beyin oğlu Uruz'un tutsak olduğu hikâyede; "Bir gün Ulaş oğlu Kazan Bey yerinden kalkmıştı. Kara yerin üzerine otağlarını diktirmişti. Bin yerde ipek halıı̆̆ı döşenmişti" (Ergin 2007: 91).

Kanlı Koca oğlu Kanturalı hikâyesinde; "Bunlar bu sözde iken meğer hanım teküre haber vardı. “Oğuz'dan Kanturalı derler bir yiğit varımış, kızını dilemeğe geliyor, dediler. ...Ağırladılar, itibar ettiler. Ak çadır diktiler; ala halı döşediler; akça koyun kırdılar; yedi yıllık al şarap içirdiler... Kan Turalı geldi, kara şapkalı teküre selâm verdi. Tekür selâm aldı. Ala halı döşediler, oturdu" (Gökyay 2000: 138-139). 


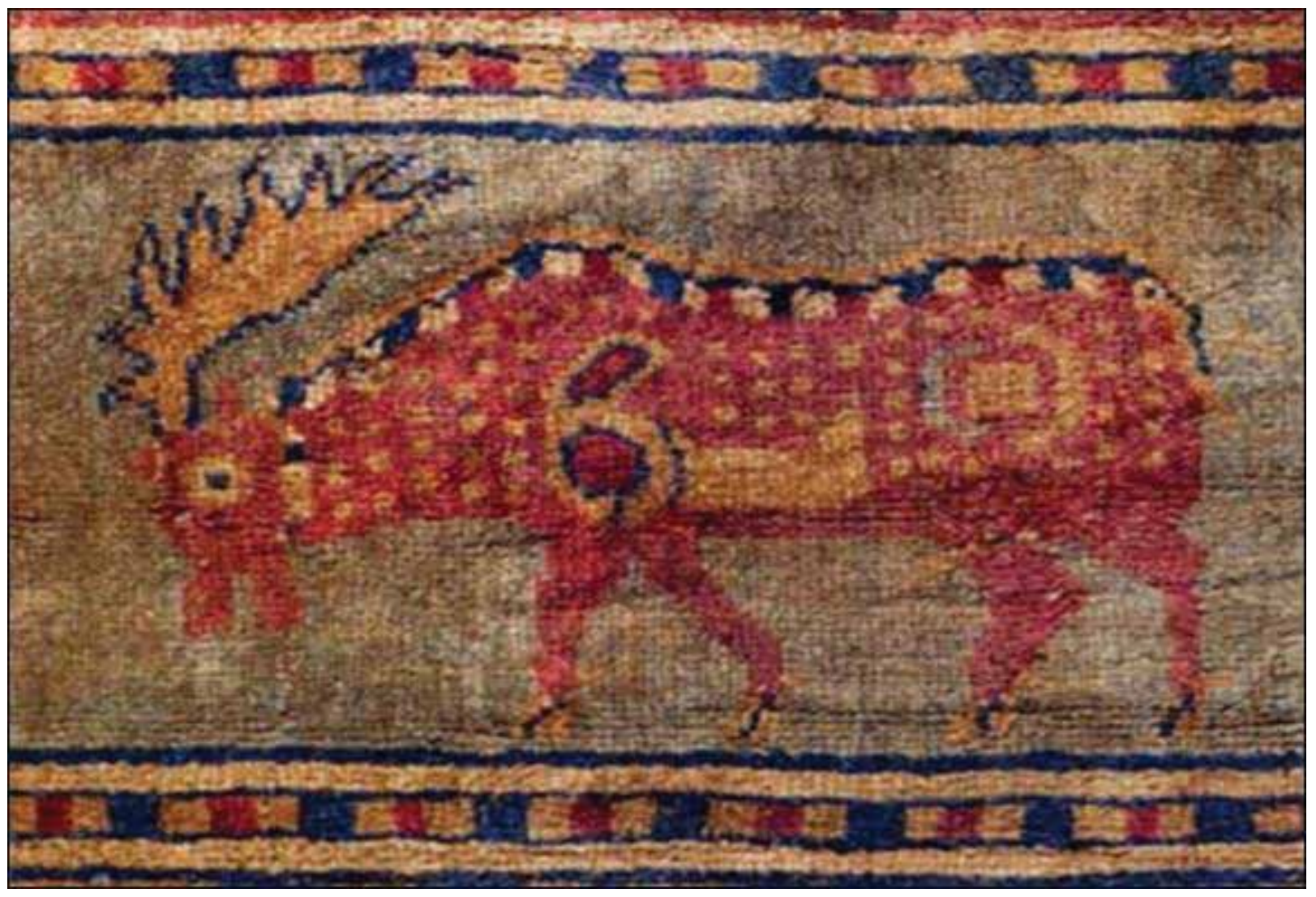

Foto 5. Pazırık Halısındaki Sı̆̆ın Tasviri

Kazılık Koca oğlu Yeğenek hikâyesinde; "Kam Gan oğlu Han Bayındır yerinden kalkmıştı. Kara yerin üzerine büyük ak çadırını diktirmişti. Ala sayvan gökyüzüne yükselmişti. Bin yerde ipek hal seccade döşenmişti" (Gökyay 2000: 159).

Begil oğlu Emren hikâyesinde halı imgesi; “Kamgan-oğlu Han Bayındır yerinden doğrulup kalkmıştı. Büyük ak çadırını kara yerin üzerine diktirmişti. Ala sayvan gökyüzüne şavk vermişti. Bin yerde ipek halı seccade döşenmişti" anlatımları ile yer almaktadır (Gökyay 2000: 188).

Toplumda yer sergisi olarak kullanılan hall; beylerin, hanların, hükümdarların masallarında, hikâyelerinde, destanlarında da her zaman kendine yer bulmuştur. Halı ilkçağlardan itibaren, yer sergisi, duvar örtüsü olarak kullanılmanın yanı sıra, hükümdarın başa geçmesi gibi resmi törenlerde de tören malzemesi olarak kullanılmıştır. Türk olduğu bilinen Tabgaç Devleti'nde ve Kök-Türklerde hükümdar seçilince halı üzerinde havaya kaldırılırdı (Deniz 2000: 9).

Tarih boyunca birçok millette olduğu gibi halı üzerinde kullanılan renklerde sadece renk olarak kullanılmamaktadır. Halı üzerine ilmek ilmek işlenen şekillere ve renklere her zaman bir sembol ve anlam yüklenmektedir. Türk tarihinin en eski dönemlerinden başlayarak bir takım sebepler ve inançlarla birlikte, milli ve manevi semboller olarak çeşitli

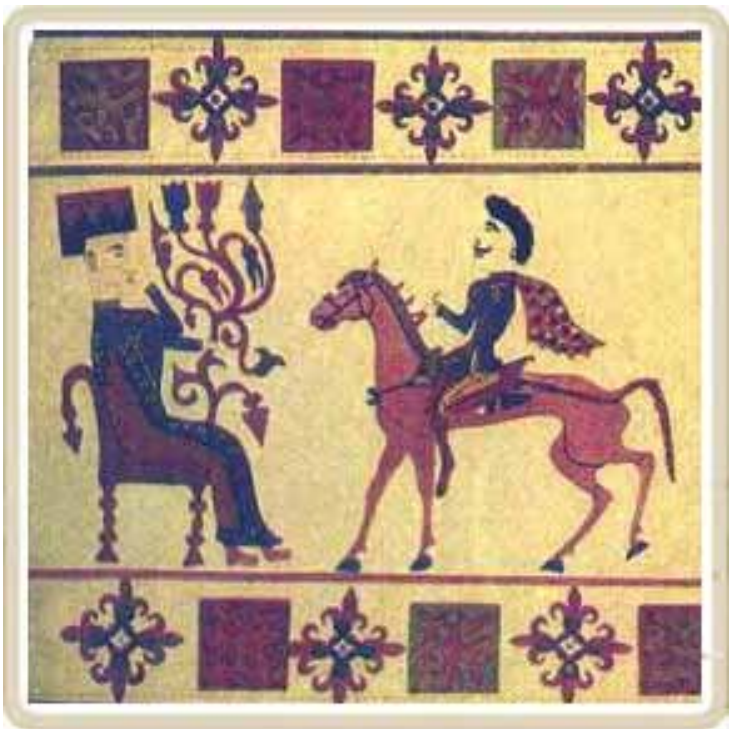

Foto 6. V. Pazırık kurganından çıkarılmış keçe örtüde yer alan Tanrıça ve atlı figürü

renklerin kullanıldığı görülmektedir. Türklerde renk, renklerin anlamı, renklerle ilgili merasimler, renklerle tabiat ve din ilişkileri, estetik açıdan yön ve renk meselesi, Nevruz ve renk ilişkisi gibi renklerle ilgili konular değişik anlamlar ifade eder. Renkler gerçek niteliklerinin yanı sıra bazen bir değer yargısı olarak da kullanılabilmektedir (Ekrem 1996: 85). Bu kültü- 


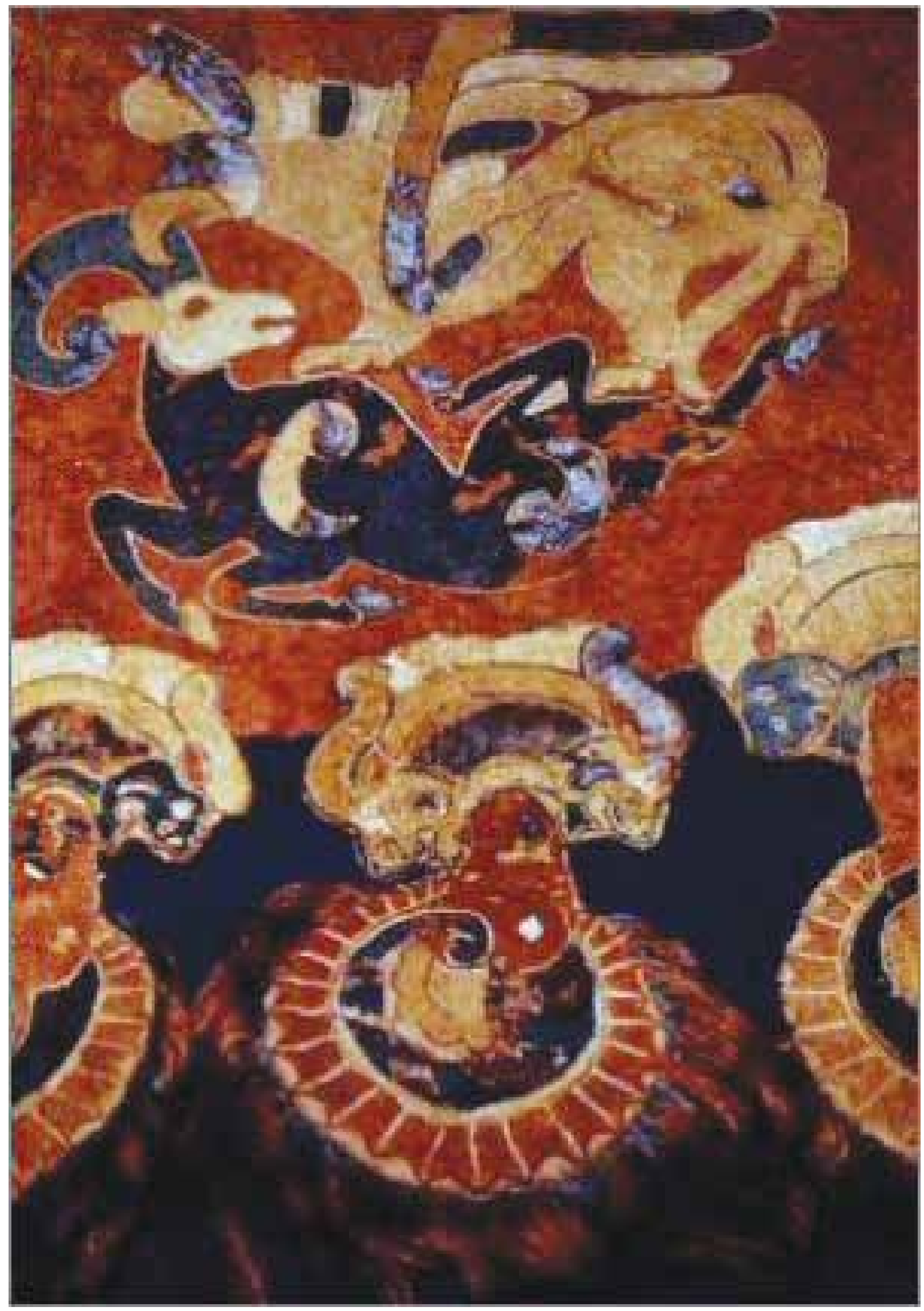

Foto 7. Pazırık kurganından çıkan eyer örtüsü 


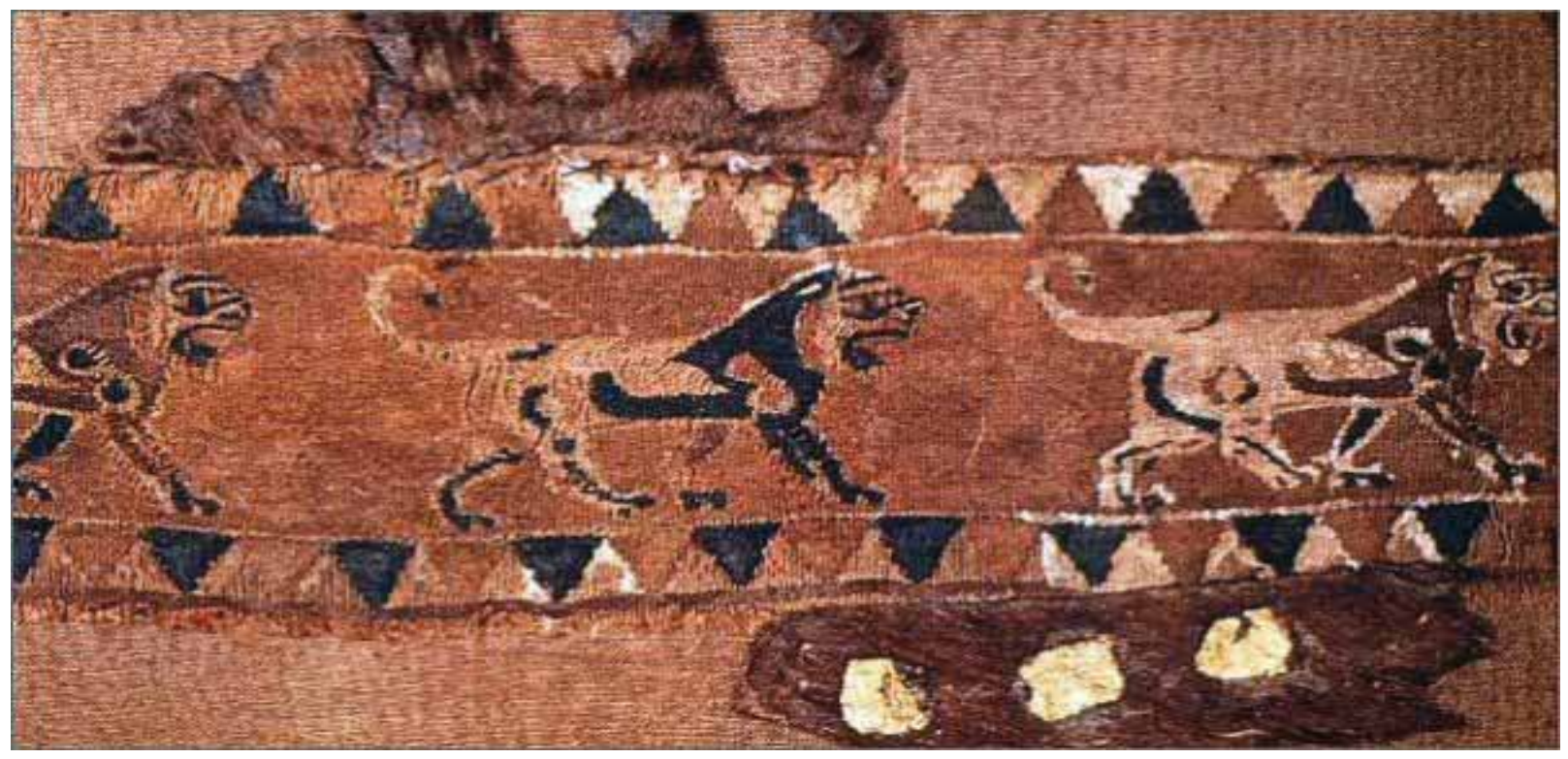

Foto 8. Bordürdeki Aslan Figürü

rel aktarımlar, değer yargısı ve simgesel anlatımlar Türk halı ve kilim sanatına da yansımış, yüzyıllar boyunca kullanımını sürdürmüş, günümüz halı ve kilimlerinde de sürdürmektedir. Pazırık halısında kullanılan renkler; kırmızı, küf yeşili, sarı-kahverengimsi renklerden oluşmaktadır (Karamağaralı 1998: 175). Kırmızı zeminin hâkim olduğu dama tahtasına benzer bir örnek gösteren Pazırık halısının, Türk Nevruz bayramını kutlamak için kullanılan simgesel renkler olan kırmızı, sarı ve yeşille de özdeşliği vardır denilebilir. Baharın gelişini karşılamak amacıyla düzenlenen Nevruz bayramında da bu üç renk ana unsur olarak karşımıza çıkmaktadır. Türk tarihindeki bu renk olgusunun Türk sanat eserleri ve Türk halı sanatıyla bağdaşlaştırılması gereklidir. Bugün dahi Türk halı ve kilimlerinde ağırlıklı olarak kırmızı, yeşil, sarı, mavi, beyaz renkler ve tonları kullanılmaktadır.

Kırmızı (Kızıl/Al) Renk: Hey'et'e göre, "kırmızı eski Türkçede yoktur. Onun yerine kızıl sözü kullanılmıştır. Kırmızı sözü Sogdca veya Farsçadan Türkçeye geçmiştir" (Hey'et 1996: 58). Bu renk Türklerde yön anlamında güneyi gösterse de, mitoloji simgeciliğinin genel anlamında güneşi, tüm savaş Tanrılarını, eril hareket ilkesini, ateşi, hükümdarlığı, aşkı, hazzı, gelin ve evlilikle ilgili bir takım hususları ifade etmektedir. Türk kültürü ve mitlerinde hem yer, hem de gök unsuruna bağlı olarak olumlu ve olumsuz anlamlar taşıyan bu renk, her iki anlamda da ortak olan güç, kuvvet, iktidar, şiddet ve yoğunluğun ifadesidir (Çoruhlu 2002: 186). Genç (1996: 41-42); Türklerin eski inançlarında "al ruhu" ya da "al ateş" adları verilen bir ateş Tanrısı'nın veya koruyucu ruhun varlığının olduğunu, Kafalı (1996: 51); kırmızının güçlülük olduğunu, Hey'et (1996: 58) ise, Türk renk sembolizminde kırmızı (kızıl) "esas renklerdendir ve tabiatta bu rengin örneği ateş (od) ve kandır, demektedir. Demek ki bu renk heyecan, kudret ve akıncılık sembolü" olduğunu söylemektedir. Ayrıca Hakanın otağı ve aşiret bayrakları, özellikle savaşta götürdükleri bayrağında kızıl renkte olduğunu bildirmektedir.

13. yüzyıl İtalyan seyyahı Marko Polo, Türkmenlerin halıları ve kumaşlarında kırmızı rengin diğer renklerden çok daha baskın bir şekilde kullandığını söylemiştir. Kırmızı renk Türkmenler için kutsallık anlamı da taşımaktadır. Onlar için güneşin doğuşu ve güneşe yakınlıktır. Aslında Türkmen halılarında kullanılan renkler: kırmızı, koyu kırmızı, lacivert, yeşil, siyah ve beyazdır. Halıdaki kırmızı renklerin hâkimiyeti, ateş rengi gibi göze çarpar. Türkmen kadınlarının giydiği elbiselerde de hakim olan renk daha ziyade kırmızı, sarı ve koyu kırmızıdır (Nurmemmet 1996: 79-80).

Sonuç olarak kırmızı (kızıl/al) rengin güneşi, tüm savaş Tanrılarını, eril hareket ilkesini, ateşi, hükümdarlığı, aşkı, hazzı, baskıyı, şiddeti, savaşı ifade etmesinin yanı sıra, üzerinde kırmızı rengi bulunduran kişiye, güç, kuvvet, kendine güven, insanlara hâkimiyet, hükmetme ve yönetme inancı verdiği, Türk halılarında kırmızının ana renk olmasını da, bu rengin koruma, kollama ve ısıtma gibi anlamlar taşıdığı söylenebilir.

Yeşil (Yaşıl) Renk: Genç'e göre, (1996: 41-42) Türk mitolojisinde hayır ilahı Ülgen'in koruyucu ruh olarak kabul edilen yedi oğlundan birinin adı "yaşıl"dır. Yaşıl, yaş olan yani yeşeren, biten, topraktan çıkan şeylerin adıdır. Yaşıl Kağan'ın umumiyetle, bitkilerin yeşerip büyümesini düzenlediğine inanılmıştır. Hey’et, (1996: 59) “tabiatta ağaçların ve bitkilerin sembolüdür. Bitkilerin göverme ve büyümeleri- 
ne sebep güneş ışığı (sarı) ve sudur (mavi). Yeşil bitki genç ve diridir. Bu yüzden yeşillik, gençlik ve hayat nişanıdır. Yeşil renk din, iman, edebiyat simgesidir" diyerek açıklama getirirken, Nurmemmet, (1996: 78) "yaşılın kökü "yaş" kelimesindendir. Oğuz Türkmenleri bazen yeşil yerine gök kelimesini kullanır. Eski Türk imparatorlukları (Avar, Gazneli gibi) bayraklarının zeminleri yeşil renktedir" demektedir. Çoruhlu'ya göre, (2002: 191-193) Uygurlarda doğunun rengi mavi bazen yeşil olarak söylenmiştir. Yeşil, ağaç kültüne bağlı olarak dünya ağacı ve hayat ağacı kavramları ile ilgilidir. Hâkimiyet ve hükümdarlık simgeciliğinden dolayı yeşil, Türk ordularında (Göktürk, Avar, Gazneli) sancak rengidir. Genel dünya simgeciliğinde yeşil, gençliği, umudu, yeniden doğuşu, cenneti, ayrıca geçicilik ve kıskançlığı, Venüs ve Merkür'ün rengi olması sebebiyle de ilkbaharı, bitkilerin çoğalmasını, bolluk, başarı ve mutluluğu ifade etmektedir.

Sarı Renk: Türk inanışları ve duygularında iyi bir yer tutmamıştır. Yalnızca tabiat ve bahardaki çiçek tasvirlerinde, zevkle ve istenerek kullanılmıştır. Sarı, bir Çin imparatorluk rengidir. Çin' in sembolü sarı ejder tasviridir. Arma, amblem ve ejderha motifi bile sarıdır. Cengiz Han imparatorluğunun genişlemesinden sonra, Türk-İslam devletlerinin amblemlerinde sarı renk çoğalmış ve yaygınlaşmıştır. Altın-Ordu hakanı ve kurucusu Batu Han'ın başkentinin adı da Sarı-Ordu'dur. Türk destanlarında sarı renklerin iyi kabul edilmediği söylenebilir. Ayrıca uçsuz bucaksız ölüm çöllerinin de sembolü sarıdır. "Sarılıg" sözü de Türkler arasında bir hastalığın adıdır. Yüzün sararması da (benzi sarardı, soldu), bir hizmeti yerine getirmemekle, utanma ve mahcup olma anlamında kullanılmıştır (Ögel 2000: 479-488).

Kafalı; (1996: 50) "dört renkle birlikte kullanılan bir beşinci renk vardır ki, oda "sarı"dır. Sarı renk yön değil, bu dört rengin ortasında yer alan merkezi karşılamak için kullanılmıştır. Devlet yapısı bakımından merkez hâkimiyetini ve kudreti ifade eder" demiştir. Türkmenler, yerin, arzın merkezinin, Ülgen'in sarayının ve tahtının sembolü olan sarı rengi ayaklarına çizme olarak, edik olarak giymişlerdir. Ayak yeri dünyanın merkezini ifade etmiştir (Genç 1996: 43). Ekrem'e (1996: 85) göre sarı renk, Çin ve Tibet kültürlerinde imparatorluk sembolü sayılırken, Türk kültüründe önemli bir yeri olmadığı gibi felaket, kötülük ve hastalığın sembolüdür. Hey'et'e (1996: 60) göre ise, güneşin rengi ve alametidir.

Dede Korkut Destanı'nda birkaç yerde geçmesine rağmen, Kanlı Koca oğlu Kanturalı hikâyesinde geçen "Güzeller şahı sarı-donlu, Salcan Hatun'u alsam", "Sarı-donlu, Salcan Hatun köşkten bakar", "Kanturalı sarı-donlu kız aşkına bir hu!", söyleyişleri yanı sıra "yanında olan bütün kızlar al giymişlerdi;
(Salcan Hatun) kendi sarı giymişti”, denilmektedir. Bu durum Salcan Hatun'un Trabuzan tekfurunun kızı olması, ya da altının renginin sarı olması, görsel ve sözsel anlatımlarda sarı renk ile tanımlandığı göz önünde bulundurulursa, zenginliği, kibarlığı ve soyluluğu ifade ettiği de söylenebilir.

Mavi (Gök) Renk: Türklerde gök, doğu yönünün simgesidir. Gök renk, gökyüzünün rengi olmasından dolayı, gök unsurunu işaret eden öğelerin simgesi olmuştur. Çeşitli mitolojilerde akıl, idrak, sağduyu, iffet, lekesizlik, sadakat, Allah'a hürmet, barış gibi erdem ve erdemlerin simgesi olan bu renk, eski Türkçe metinlerde geçen "gök böri" terimi ile Gök Tanrı'yı da simgelemektedir. Eski Türklerde demirin kutsal sayılması demir, çelik, gümüş gibi maden ve maden alaşımlarının bu renkle ilişkilendirilmesiyle de alakalıdır (Çoruhlu 2002: 188). "Gök girsin, kızıl çıksın" cümlesi buna eş değerdir. Hey'et, (1996: 55) "Türkler zevk düşünce ve inanışlarına göre bazı renkleri sevip, onları uğurlu saymışlardır. Hatta bazen bir renge ilahi bir boya da vermişler ve onu Tanrı'nın rengi gibi kabul etmişlerdir (gök rengi gibi)" derken, Kadeşeva (1996: 95) ise, "Mavi renge karşı saygı, bütün Türk halklarında vardır. Eski inançlara göre bu renk, Tanrı rengidir. Gök kelimesi genel olarak yaşamak, yenilenmek, gençleşmek anlamını verir" demektedir.

Ögel, (2000: 457-471) “Türk Kültür Tarihine Giriş (C.6)" kitabında bu konuya uzun uzun değinmiş ve şu sonuçlara varmıştır;

Gök, gökyüzünün rengi ve dünyamızın varlığıdır: Gök, Tanrı'nın ve bizi sonsuzluklara bağlayan, ululuk ve yüceliğin bir sembolüdür. İnsanlara bolluk ve refah ile ölüm ve felaket, yine gökten gelir.

Gök renk Türklerde, Tanrı'nın rengi ve sembolüdür: Oğuz Kağan Destanı'nda “Ufukta gök bir kurt (böri) görünür. Oğuz Kağan'ın ordusu kurdu izler. Kurt, bir yerde kaybolur. Oğuz Kağan, Tanrı bizim buraya gelmemizi buyurdu der ve orada durur". Burada gök kurt Tanrısallığın simgesi durumundadır.

Din inanışları ve gök renk: Çeşitli ruh, cin ve nazarlar, gök renk ile tanıtıldığı gibi süs eşyaları ve nazarlıklar arasında da gök deyimi ve rengi kullanılmıştır.

Yasta ve ölümde gök renk: Dede Korkut Destanı'nda, Bamsı Beyrek hikâyesinde "karalı göklü otağı sorar olsan, gölge kimin; Ağam Beyreğindir,

.. kız kardaşları karalı-göklü bir arada oturuyorlar", sözleri ile ortaya konarak Beyreğin öldüğünü sanan ailesinin yas sahneleri anlatılmıştır. Burada Türk aile bağlarının ne kadar güçlü olduğu da belirtilmiş olmaktadır.

Hayvanlarda gök renk: Gök Kurt'un (Gök Böri), Tanrı'nın alamet ve habercisi anlayışı dışında "GökTeke", kayalıklarda ve yüce dağlarda geyikleri peşine takıp götüren ulu ve baba geyikler Türk destanların- 
da geçen sembollerdendir. Tanrı Dağları üzerinde hayvancılık yapan Kırgız Türkleri'de sürüleri güden teke ve koçlara "Gök-Serke" demişlerdir. Dede Korkut Destanı'nda "gök bidevi at" sözünden bu atların değerli ve eşsiz atlar olduğu düşünülmektedir.

Türklerde gök anlayışı, manevi yükselişin, temizliğin, Tanrı'ya doğru yücelen ruhların rengidir. Dede Korkut Destanı'nda geçen "gök sakallı" ifadesi ile ermişliğe, ululuğa işaret etmektedir. Aynı zamanda soyluluğa işaret eden bir simge olmasının yanında bu renk yas, matem, cenaze ve ölüm anlamı yanında yaşamak, yenilenmek, gençleşmek manalarını da içerdiği görülmektedir.

\section{Sonuç}

Destanlar, bir milletin hafızasında yüzyıllar içerisinde şekillenmiş, o milletin var olmasını, kahramanlarını, tarihindeki geçmiş olaylarını, dinsel ve töresel inançlarını, elemlerini, kederlerini, sevinç ve coşkunluklarını kısaca tarihini hareketlendiren bütün duygu ve düşünce yapısını oluşturan zenginlik hazineleridir. Milletlerin millet olma yolundaki çabalarından izler taşımakta ve bu çabaların hatıraları ile geçmişle gelecek arasındaki zamanı canlı ve taze tutmaktadır. Halı ve kilimlerin de önemli bir kültürel aktarım aracı olarak destanlar içerisinde yer bulması ile de milletlerin geçmişlerindeki kültürel birikimlerinin geleceğe aktarılmasındaki faydası unutulmamalıdır. Halı-kilimlerdeki her ilmek, her nakış, her motif, figür, sembol ve şekiller tarihin akışını izleyerek gelmiş, tarih sayfaları içinde kendine yer bulmuş, dokuyucusunun ruhundan akan miraslık tarihi vesikalar ve eserlerdir.

Kaynaklar

Aksoy Mustafa (2007a), "Kültür Sosyolojisi Açısından HalıKilim Sanatı ve Etnografik Eserlerdeki Damgaların Dili", Uluslar arası Asya ve Kuzey Afrika Çalışmaları Kongresi. 38. ICANAS, 10-15 Eylül 2007, Ankara: Atatürk Kültür, Dil ve Tarih Yüksek Kurumu.

Aksoy, Mustafa (2007b), “İran'daki Fars Kürt ve Türklere Ait Halı-Kilimlerin Kültür Sosyolojisi Açısından Yorumu", Türk Kültür ve Sanatından Kesitler, Konya: Kömen Yayınları.

Çoruhlu, Yaşar (2002), Türk Mitolojisinin Ana Hatları, İstanbul: Kabalcı Yayınevi.

Diyarbekirli, Nejat (1969), Türk Sanatının Kaynaklarına Doğru İstanbul: Türk Sanatı Tarihi Araştırma ve İncelemeleri.

Diyarbekirli, Nejat (1972), Hun Sanatı, İstanbul: Milli Eğitim Basımevi.

Deniz, Bekir (2000), Türk Dünyasında Halı ve Düz Dokuma Yaygıları, Ankara: Atatürk Yüksek Kurumu, Atatürk Kültür Merkezi Yayını: 215.

Ekrem, Nuraniye. H. (1996), "Nevruz ve Renkler", Hunlarda Renk ve Yön Bilgisi, Türk Dünyasında Nevruz İkinci Bilgi Şöleni Bildirileri, Ankara, 19-21 Mart 1996, AKM Yayını, S. 11.

Ergin, Muharrem (2007), Dede Korkut Kitabı, İstanbul: Boğaziçi Yayınları.
Esin, Emel (2004), Türk Sanatında İkonografik Motifler, İstanbul: Kabalcı Yayınları.

Genç, Reşat (1996), "Nevruz ve Renkler", Türk Düşüncesi, Davranışı ve Hayatında Renkler ve Sarı, Kırmızı, Yeşil, Nevruz ve Renkler, Türk Dünyasında Nevruz İkinci Bilgi Şöleni Bildirileri, Ankara, 19-21 Mart 1996, Yayına Hazırlayanlar: Sadık Tural-Elmas Kılıç, Ankara: Atatürk Kültür Merkezi Yayını, S. 116.

Gökyay, Orhan Şaik (2000), Dede Korkut Hikayeleri, Ankara: Kültür Bakanlığı Yayınları.

Hey'et, Cevat (1996), "Nevruz ve Renkler", Türklerin Tarihinde Renklerin Yeri, Türk Dünyasında Nevruz İkinci Bilgi Şöleni Bildirileri, Ankara, 19-21 Mart 1996, Yayına Hazırlayanlar: Sadık Tural - Elmas Kılıç, Ankara: Atatürk Kültür Merkezi Yayını, s. 116.

Kadaşeva, Karlıgaş (1996), "Nevruz ve Renkler", Kazak Medeniyetindeki Semboller, Aktaran: Medine Ahmetova, Türk Dünyasında Nevruz İkinci Bilgi Şöleni Bildirileri, Ankara, 19-21 Mart 1996, Yayına Hazırlayanlar: Sadık Tural - Elmas Kılıç, Ankara: Atatürk Kültür Merkezi Yayını, S. 116.

Karamağaralı, Beyhan (1998), "Halı Sanatı Üzerine”, Türk Soylu Halkların Halı Kilim ve Cicim Sanatı, Uluslararası Bilgi Şöleni Bildirileri, 27-31 Mayıs 1996 Kayseri, Ankara: AKM Başkanlığı Yayınları.

Kafalı, Mustafa (1996), "Nevruz ve Renkler", Türk Kültüründe Renkler, Türk Dünyasında Nevruz İkinci Bilgi Şöleni Bildirileri, Ankara, 19-21 Mart 1996, Yayına Hazırlayanlar: Sadık Tural-Elmas Kılıç, Ankara: Atatürk Kültür Merkezi Yayını, S. 116

Kırzıoğlu, Fahrettin (1987), "Milli Destanlarımızdan Dede Korkut Oğuznameleri'nin Tarih Belgesi Bakımından Değerleri - Armenya / Yukarı Eller Tarihi'nin İçyüzü", Belleten, C. L, S.198 (Aralık 1986)'dan ayrı basım, Ankara: Türk Tarih Kurumu Basımevi.

Kırzıoğlu, Neriman G. (2001), Altaylar'dan Tunaboyu'na Türk Dünyası'nda Ortak Yanışlar (Motifler), Ankara: Kültür Bakanlığı Yayınları, s. 59.

Mülayim, Selçuk (1998), "Tanımsız Figürlerin İkonografisi”, Türk Soylu Halkların Halı Kilim ve Cicim Sanatı, Uluslar arası Bilgi Şöleni Bildirileri, 27-31 Mayıs 1996, Kayseri, Ankara: AKM Başkanlığı Yayınları.

Nurmemmet, Annagulu (1996), "Nevruz ve Renkler", Türkmenlerde Renk Dünyası ve Nevruz, Türk Dünyasında Nevruz İkinci Bilgi Şöleni Bildirileri, Ankara, 19-21 Mart 1996, Yayına Hazırlayanlar: Sadık Tural-Elmas Kılıç, Ankara: Atatürk Kültür Merkezi Yayını, S. 116.

Ögel, Bahaeddin (2000), Türk Kültür Tarihine Giriş, TC. Kültür Bakanlığı Yayınları / 638, Ankara: Gazi üniversitesi İletişim Fakültesi Basımevi.

Özhekim, Didem A. (2007), "Hayvan Figürlü Tekstillerde Kartal Sembolü" I. Uluslar arası Türk El Dokumaları Kongresi, 01-02 Kasım 2007, Konya, SÜ. Selçuklu Araştırmaları Merkezi Başkanlığı Yayınları.

Paşayeva, Valide (2008), "Azerbaycan Halı ve Tekstillerinde Ejder Motifi", Uluslararasl Asya ve Kuzey Afrika Çalısmaları Kongresi, 38. ICANAS, 10-15 Eylül 2007, Ankara: Atatürk Kültür, Dil ve Tarih Yüksek Kurumu.

Tekçe, E. Fuat (1993), Pazırık, Altaylardan Bir Halının Öyküsü, Ankara: Kültür ve Turizm Bakanlığı Yayınları.

Uzun, Tolga (2007), Türk Sanatındaki Kartalların İkonografisi ve Devamllığı, http://egitimdergi.pamukkale.edu.tr 